17. Norum KR, Gjone E 1967 Familial plasma lecithin:cholesterol acyltransferase deficiency. Biochemical study of a new inborn error of metabolism. Scand J Clin Lab Invest 20:231-243

18. Orenstein SR, Whitington PF 1983 Choledochal cyst resulting in congenital cirrhosis. Am J Dis Child 136:1025-1026

19. Poley JR, Alaupovic P, Knight-Gibson C, and Caplan DB 1983 The quantitative determination of serum lipoprotein- $X$ and apolipoproteins in infants with cholestatic liver and biliary tract disease. In: Daum F (ed) Extrahepatic Biliary Atresia. Marcel Dekker, New York, pp 33-41

20. Poley JR, Alaupovic P, McConathy WJ, et al 1973 Diagnosis of extrahepatic biliary obstruction in infants by immunochemical detection of LP.X and modified ${ }^{131}$ I-rose bengal excretion test. $J$ Lab Clin Med 81:325-341

21. Ritland S, Blomhoff JP, and Gjone E 1973 Lecithin:cholesterol acyltransferase and lipoprotein-X in liver disease. Clin Chim Acta 49:251-259

22. Rouser G, Fleischer S, and Yamamoto AP 1969 Two dimensional thin layer chromatographic separation of polar lipids and determination of phospholipids by phosphorus analysis of spots. Lipids 5:494-496

23. Sabesin SM 1982 Cholestatic lipoproteins-their pathogenesis and significance. Gastroenterology 83:704-709

24. Sabesin SM, Bertram PD, and Freeman MR 1980 Lipoprotein metabolism in liver disease. Adv Intern Med 25:117-146

25. Sabesin SM, Ragland JB, and Freeman MR 1979 Lipoprotein disturbances in liver disease. Popper H, Schaffner F (eds) Progress in Liver Diseases. Grune and Stratton, New York, pp 243-262
26. Sanar J, Skrede S, and Blomhoff JP 1978 Hepatic lipase and lipoprotein lipase in postheparin plasma in liver disease. Relations to plasma proteins. Clin Chim Acta 84:213-223

27. Seidel D, Alaupovic P, and Furman RH 1969 A lipoprotein characterizing obstructive jaundice. I. Method for quantitative separation and identification of lipoproteins in jaundiced subjects. J Clin Invest 48:1211-1223

28. Seidel D, Alaupovic P, Furman RH, et al 1970 A lipoprotein characterizing obstructive jaundice. II. Isolation and characterization of protein moieties of low-density lipoproteins. J Clin Invest 49:2396-2407

29. Turner KB, McCormack GH Jr, Richards A 1953 The cholesterol esterifying enzyme of human serum. I. In liver disease. J Clin Invest 32:801-806

30. Weber K, and Osborn M 1969 The reliability of molecular weight determination by dodecyl sulfate-polyacrylamide gel electrophoresis. J Biol Chem 244:4406

31. Weidman SW, Ragland JB, Fisher JN, et al 1982 Effects of insulin on plasma lipoproteins in diabetic ketoacidosis: evidence for a change in high density lipoprotein composition during treatment. J Lipid Res 23:171-182

32. Weidman SW, Ragland JB, Jones WE, et al 1984 Plasma lipoprotein composition in cholestasis: accumulation of abnormal lipoproteins and changes during partial recovery. Hepatology (in press)

33. Weidman SW, Ragland JB, and Sabesin SM 1982 Plasma lipoprotein composition in alcoholic hepatitis: accumulation of apolipoprotein E-rich high density lipoproteins and preferential reappearance of "light"-HDL during partial recovery. J Lipid Res 23:556-569

\title{
Heat- and Alcohol-Induced Neural Tube Defects: Interactions with Folate in a Golden Hamster Model
}

\author{
JOHN M. GRAHAM, JR. AND VERGIL H. FERM \\ Dysmorphology Unit, Department of Maternal and Child Health [J.M.G.], and Department of Anatomy, \\ Dartmouth Medical School [V.H.F.J, Hanover, New Hampshire 03756
}

\begin{abstract}
Maternal hyperthermia or ethanol each can induce fetal neural tube defects (NTD) following exposures on the 8th day of gestation in golden hamsters. To explore the relationship between NTD and varying doses of either heat or ethanol, timed pregnant golden hamsters were exposed to various doses of either $25 \%$ ethanol, or heat in an incubator at $39.5^{\circ} \mathrm{C}$ on the morning of the 8th day of gestation. Two doses of $0.015 \mathrm{ml} / \mathrm{g}$ body weight of $25 \%$ ethanol $4 \mathrm{~h}$ apart resulted in a $44 \%$ incidence of NTD when fetuses were examined on day 13. Single doses of $25 \%$ ethanol (either 0.015 or $0.0075 \mathrm{ml} / \mathrm{g}$ ) resulted in very low incidences of NTD that were not significantly different from zero. A 50-min exposure to heat resulted in a $35 \%$ incidence of NTD. A shorter exposure (44 min) resulted in a $23 \%$ incidence, and a longer exposure $(56 \mathrm{~min})$ resulted in a $68 \%$ incidence of NTD. A $0.0075 \mathrm{ml} / \mathrm{g}$ dose of $25 \%$ ethanol, followed by these same durations of heat, resulted in incidences of NTD that were not significantly different from heat alone. In order to determine what effect folate supplementation might have on ethanol- or heat-induced
\end{abstract}

Received March 12, 1984; accepted October 2, 1984.

Address for Reprints John M. Graham, Jr., M.D., ScD., Dysmorphography Unit, Department of Maternal and Child Health, Dartmouth Medical School, Hanover, NH 03756.

Supported by BRSG Grant 2507-RR05392-21 [J.M.G.], Hitchcock Foundation Research Project Grant 51 [J.M.G.], and NIH Grant OH-01434 [V.H.F.]

\begin{abstract}
NTD, osmotic pumps filled with either folate or saline were placed subcutaneously in pregnant hamsters on the 6th day of gestation. Animals were then exposed to ethanol or heat on the morning of day 8 . No significant protection from NTD was evident among fetuses from mothers supplemented with folate despite significant elevations in their red cell folate levels on day 8 of gestation. (Pediatr Res 19: 247-251, 1985)
\end{abstract}

Abbreviation

NTD, neural tube $\operatorname{defect}(\mathrm{s})$

Experimental results from several animal species suggest that hyperthermia during the time of neural tube closure may lead to NTD $(7,8,15,26)$. Furthermore, epidemiologic studies suggest the human embryo is not immune to such effects $(2,10,14,21)$. Such studies suggest that as many as $10 \%$ of live births and $14 \%$ of human abortuses with NTD may have been exposed to hyperthermia during early gestation (25). Other studies have documented frequent occurrences of anencepahly following epidemics of febrile illnesses such as influenza $(5,6,13)$. Similarly, experimental studies suggest that exposure to high doses of 
ethanol during the time of neural tube closure results in a significantly increased incidence of $\operatorname{NTD}(3,16,22,31,33)$. A number of anecdotal human case reports also suggest that NTD are among the central nervous system malformations that have been observed in the wake of heavy drinking during early gestation $(4,11,12,20)$. Other workers have suggested that perinatal vitamin supplementation, particularly with folate, might be effective in preventing NTD recurrences $(18,28,30)$.

We have shown that NTD are readily induced by heat in the hamster model system (15). In addition, in the present study we show that ethanol is capable of inducing NTD in the hamster, confirming similar results in mice and chickens $(3,16,22,28$, $31,33)$. If folate supplementation affords protection from teratogen-induced NTD, then it should reduce the incidence of NTD induced by either heat or alcohol in such an experimental animal system. Herein we report the effect of folate supplementation prior to and during the stages of critical embryogenesis for neural tube closure in the golden hamster.

\section{METHODS}

In the golden hamster, neural tube closure occurs between $8.00 \mathrm{~h}$ on day 8 and $8.00 \mathrm{~h}$ on day 9 , counting the first postconceptual day as day 1 (9). Timed pregnant golden hamsters were exposed to various doses of $25 \%$ ethanol administered by intraperitoneal injection, or varying durations of heat in a waterjacketed Thelco incubator on the morning of day 8. Doses of ethanol were $0.0075 \mathrm{ml} / \mathrm{g}$ body weight, $0.015 \mathrm{ml} / \mathrm{g}$ or two doses of $0.015 \mathrm{ml} / \mathrm{g}$ administered $4 \mathrm{~h}$ apart. Heat exposures were for 44,50 , or $56 \mathrm{~min}$ at $39.5^{\circ} \mathrm{C}$. In order to test for possible interaction between heat and alcohol, animals were pretreated with $0.0075 \mathrm{ml} / \mathrm{g} 25 \%$ ethanol and then exposed to either 44 , 50 , or 56 min of dry heat on the morning of day 8 . This dose of alcohol was chosen because, when given alone, it did not result in a significantly increased rate of fetal resorption or fetal malformation.

Blood alcohol levels at various times after injection of either 0.0075 or $0.0015 \mathrm{ml} / \mathrm{g} 25 \%$ ethanol were determined on day 13 . Blood samples were drawn by cardiac puncture just prior to sacrifice. Samples were collected in heparinized venipuncture tubes. Blood alcohol levels were measured by the Clinical Laboratory of the Dartmouth-Hitchock Medical Center, using the method developed by Calbiochem-Behring (Ethyl Alcohol STAT-PACK). Each sample was run in duplicate, and values showing significant variation between the two separate determinations were rejected.

Osmotic pumps (Alzet model 2001) were filled with $250 \mu \mathrm{l}$ of either a folic acid parenteral solution (Tradename Folvite, Lederle) containing $5 \mathrm{mg}$ folic acid per $\mathrm{ml}$ or normal saline. Pumps were allowed to equilibrate in a saline solution for $4 \mathrm{~h}$ prior to being inserted subcutaneously on the afternoon of day 6 . On activation, the pumps release their contents at a constant rate of $1 \mu \mathrm{l} / \mathrm{h}$. After anesthetizing each animal with sodium pentobarbital, a $1-\mathrm{cm}$ midline incision was made through the skin on the back, and a single pump was inserted subcutaneously. The skin was closed with surgical clips. Forty hours later, on the morning of day 8 , animals were treated with either two doses of $0.015 \mathrm{ml} /$ g $25 \%$ ethanol or $50 \mathrm{~min}$ of heat. This time was chosen because it is the period of initial embryogenesis for neural tube closure in this species (9).

Blood was drawn for folate determinations via cardiac puncture on either day $8,9,12$, or 13 after light ether anesthesia. Red cell folate levels were determined by radioassay in the laboratory of Dr. Brinck-Johnsen at the Dartmouth Medical School using the Corning Folate Radioassay kit (IMMO PHASE). Red cell folate levels were utilized because they are not subject to fluctuations due to daily folate intake and therefore provide more conclusive evidence of folate status. Samples were collected in glass tubes containing EDTA as an anticoagulant and frozen immediately after determining the hematocrit. Red cell folate levels were run in batches on duplicate paired samples and repeated if paired results differed by more than $15 \%$.

Animals were sacrificed for fetal examination on the morning of day 13 and the number of sacs and resorption sites were recorded. All unresorbed fetuses were examined under a dissecting microscope for the presence of external anomalies, with particular attention to the head, limbs, back, and ribs (which could be visualized through translucent skin).

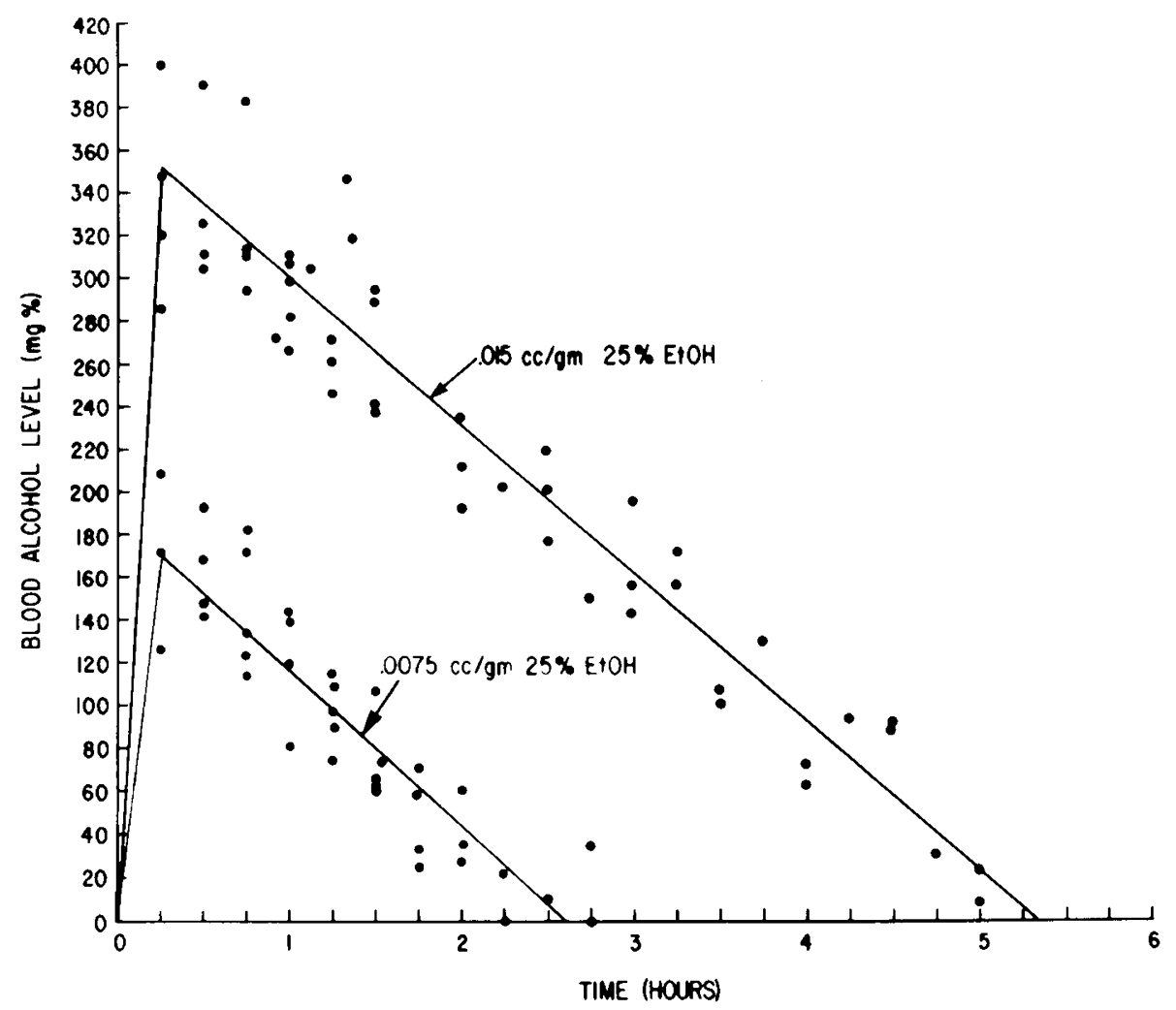

Fig. 1. Blood alcohol metabolic curves in the pregnant golden hamster. 


\section{RESULTS}

A single dose of $0.015 \mathrm{ml} / \mathrm{g}$ of $25 \%$ ethanol resulted in blood alcohol levels of about $350 \mathrm{mg} / 100 \mathrm{ml}$ in $15 \mathrm{~min}$ (generally considered to be consistent with severe intoxication in the human); these levels gradually fell to 0 over the next $5 \mathrm{~h}$ (Fig. 1). Hamsters treated with this dose of alcohol appeared heavily sedated for the first 1 to $2 \mathrm{~h}$, but were moving about with an unsteady gait within $2 \mathrm{~h}$. Half of this dose $(0.0075 \mathrm{ml} / \mathrm{g})$ resulted in an average blood alcohol level of $175 \mathrm{mg} / 100 \mathrm{ml}$ in $15 \mathrm{~min}$, and these levels gradually fell to 0 by about $2^{1 / 2} \mathrm{~h}$. Animals treated with this dose usually were moving about with an unsteady gait within $1 \mathrm{~h}$. Exposure to 44, 50, or $56 \mathrm{~min}$ of heat was sufficient to elevate core body temperature 3 to $5^{\circ} \mathrm{C}$ as measured by a rectal temperature probe (YSI-TeleThermometer).

Except for saline pump controls, each treatment group included 10 to 15 litters. As shown in Table 1, there were no

Table 1. Rates of fetal resorption by treatment group

\begin{tabular}{|c|c|c|c|}
\hline $\begin{array}{l}\text { Treatment } \\
\text { group }\end{array}$ & $\begin{array}{l}\text { Total no. } \\
\text { of litters }\end{array}$ & $\begin{array}{l}\text { Total no. } \\
\text { of sacs }\end{array}$ & $\%$ resorbed \\
\hline Saline & 15 & 187 & 5 \\
\hline $0.0075 \mathrm{ml} / \mathrm{g} \mathrm{EtOH}^{*}$ & 12 & 164 & 3 \\
\hline $0.015 \mathrm{ml} / \mathrm{g} \mathrm{EtOH}{ }^{*}$ & 14 & 181 & 7 \\
\hline 2 Doses $0.015 \mathrm{ml} / \mathrm{g} \mathrm{EtOH}$ & 13 & 163 & 7 \\
\hline 2 Doses $0.015 \mathrm{ml} / \mathrm{g} \mathrm{EtOH}^{*}+$ & 13 & 200 & 5 \\
\hline 2 Doses $0.015 \mathrm{ml} / \mathrm{g} \mathrm{EtOH}^{*,}$ & 7 & 100 & 5 \\
\hline 44 mins heat & 13 & 194 & 2 \\
\hline 50 mins heat & 12 & 163 & 10 \\
\hline $56 \mathrm{~min}$ heat & 13 & 182 & 27 \\
\hline 50 min heat $\uparrow$ & 13 & 188 & 5 \\
\hline 50 min heat & 8 & 117 & 9 \\
\hline $\begin{array}{l}0.0075 \mathrm{ml} / \mathrm{g} \mathrm{EtOH}^{*} \text { then } 44 \\
\text { min heat }\end{array}$ & 12 & 158 & 6 \\
\hline $\begin{array}{l}0.0075 \mathrm{ml} / \mathrm{g} \mathrm{EtOH}{ }^{*} \text { then } 50 \\
\text { min heat }\end{array}$ & 12 & 182 & 26 \\
\hline $\begin{array}{l}0.0075 \mathrm{ml} / \mathrm{g} \mathrm{EtOH}^{*} \text { then } 56 \\
\text { min heat }\end{array}$ & 10 & 139 & 14 \\
\hline
\end{tabular}

$* 25 \%$ ethyl alcohol.

$\dagger$ Folate pump inserted on day 6.

$\ddagger$ Saline pump inserted on day 6 . significant differences in resorption rates with varying amounts of alcohol; however, increasing durations of heat exposure resulted in increased fetal resorption. Pretreatment with a half dose of ethanol just prior to heat exposure further increased the incidence of resorption, except at the 56-min duration when there was significantly higher maternal mortality associated with alcohol pretreatment. More than one-third of the mothers treated in that way failed to survive the treatment. With a 56-min heat exposure, there was a $35 \%$ maternal mortality following alcohol pretreatment, while heat alone for $56 \mathrm{~min}$ resulted in a $7 \%$ maternal mortality. The maternal mortality rate for a $50-\mathrm{min}$ heat exposure after alcohol pretreatment was $24 \%$ versus $13 \%$ for heat alone at this duration. Heat exposure for $44 \mathrm{~min}$ did not result in any maternal deaths.

Dose-related trends were observed in the incidence of NTD with increasing amounts of alcohol; however, only the treatment with two doses of $0.015 \mathrm{ml} / \mathrm{g}$ ethanol $4 \mathrm{~h}$ apart reached statistical significance (Table 2). Figure 2 demonstrates differing outcomes observed in three fetuses from one litter exposed to two such doses of alcohol. Within the same litter, it was common to find both normal and abnormal fetuses. As shown in Table 2, the percent of NTD increased from 23 to 35 to $68 \%$ with increasing durations of heat ( $p=0.03$ by $\mathrm{F}$ test). Pretreatment with a half dose of alcohol did not result in incidences of NTD that were significantly different from heat alone (Fig. 3).

Animals treated with low doses of $25 \%$ ethanol (either 0.0075 or $0.015 \mathrm{ml} / \mathrm{g}$ ) did not demonstrate an increased incidence of NTD. The incidences of NTD in these animals were not significantly greater than zero (the rate observed in 15 saline-injected control litters and six uninjected control litters). Two doses of $0.015 \mathrm{ml} / \mathrm{g} 25 \%$ ethanol injected $4 \mathrm{~h}$ apart resulted in a significant increase in NTD ( $p<0.01$ by Mann-Whitney U test).

As shown in Figure 4, animals with folate pumps had significantly higher red cell folate levels on day 8 , and the levels continued to rise over the next 5 days. The incidence of NTD among folate-supplemented animals treated with either heat for $50 \mathrm{~min}$ or two doses of $0.015 \mathrm{ml} / \mathrm{g}$ ethanol $4 \mathrm{~h}$ apart were not significantly different by $t$ test analysis from saline pump controls or similarly treated animals without pumps (Tables 1 and 2).

\section{DISCUSSION}

NTD can be induced experimentally in laboratory animals by many different experimental insults during the time of neural

Table 2. Rates of CNS malformation by treatment group

\begin{tabular}{|c|c|c|c|c|c|c|}
\hline $\begin{array}{l}\text { Treatment } \\
\text { group }\end{array}$ & $\begin{array}{l}\text { Total no. of } \\
\text { litters }\end{array}$ & $\begin{array}{l}\text { Total no. of } \\
\text { fetuses }\end{array}$ & $\begin{array}{l}\text { No. of litters } \\
\text { with NTD }\end{array}$ & $\begin{array}{l}\text { No. of fetuses } \\
\text { with NTD }\end{array}$ & $\%$ NTD & $\begin{array}{c}\% \text { fetuses with } \\
\text { exencephaly }\end{array}$ \\
\hline Saline & 15 & 177 & 0 & 0 & 0 & 0 \\
\hline $0.0075 \mathrm{ml} / \mathrm{g} \mathrm{EtOH}^{*}$ & 12 & 158 & 1 & 1 & 1 & 0 \\
\hline $0.015 \mathrm{ml} / \mathrm{g} \mathrm{EtOH}^{*}$ & 14 & 169 & 2 & 4 & 2 & 1 \\
\hline 2 Doses $0.015 \mathrm{ml} / \mathrm{g}$ EtOH* & 13 & 151 & 12 & 67 & 44 & 28 \\
\hline 2 Doses $0.015 \mathrm{ml} / \mathrm{g} \mathrm{EtOH}^{*, \dagger}$ & 13 & 190 & 11 & 83 & 44 & 23 \\
\hline 2 Doses $0.015 \mathrm{ml} / \mathrm{g} \mathrm{EtOH} *$ & 7 & 95 & 7 & 36 & 38 & 20 \\
\hline 44 min heat & 13 & 191 & 7 & 44 & 23 & 3 \\
\hline 50 min heat & 12 & 147 & 7 & 52 & 35 & 15 \\
\hline $50 \mathrm{~min}$ heat & 13 & 133 & 12 & 91 & 68 & 32 \\
\hline 50 min heat $\dagger$ & 13 & 178 & 11 & 87 & 49 & 13 \\
\hline 50 min heat $\ddagger$ & 8 & 107 & 7 & 48 & 46 & 8 \\
\hline $\begin{array}{l}0.0075 \mathrm{ml} / \mathrm{g} \mathrm{EtOH} \text { * then } 44 \\
\text { min heat }\end{array}$ & 12 & 149 & 6 & 33 & 22 & 3 \\
\hline $\begin{array}{l}0.0075 \mathrm{ml} / \mathrm{g} \mathrm{EtOH}{ }^{*} \text { then } 50 \\
\text { min heat }\end{array}$ & 12 & 135 & 11 & 45 & 33 & 14 \\
\hline $\begin{array}{l}0.0075 \mathrm{ml} / \mathrm{g} \mathrm{EtOH}^{*} \text { then } 56 \\
\text { min heat }\end{array}$ & 10 & 114 & 10 & 87 & 73 & 44 \\
\hline
\end{tabular}

* $25 \%$ ethyl alcohol.

$\dagger$ Folate pump inserted on day 6.

$\ddagger$ Saline pump inserted on day 6 . 


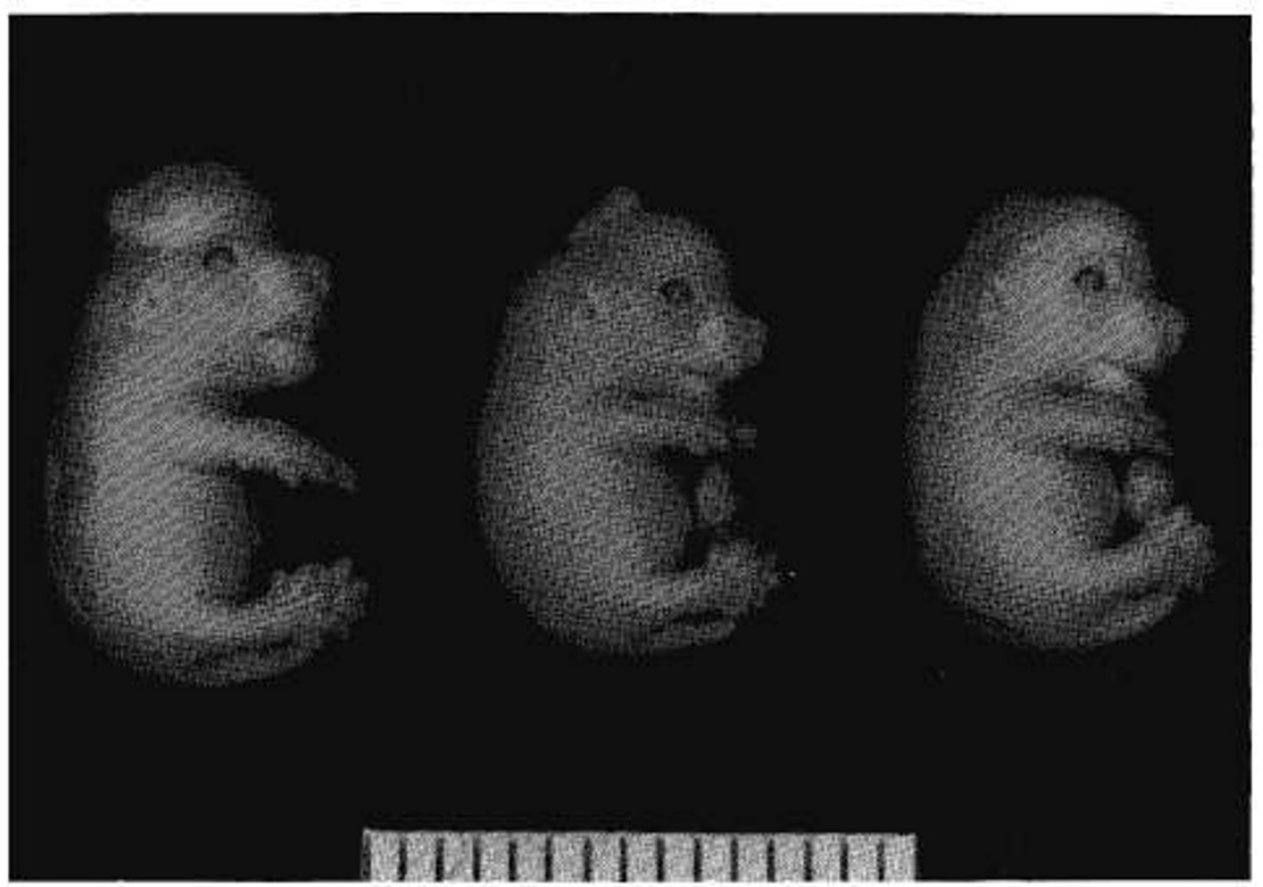

Fig. 2. Three 13-day hamster fetuses from one litter exposed to two doses of $0.015 \mathrm{mg} / \mathrm{g}$ body weight $25 \%$ intraperitoneal ethanol administered $4 \mathrm{~h}$ apart, on the morning of day 8 . The fetus on the left demonstrates exencephaly, the center fetus has an encephalocele, and the fetus on the right is grossly normal.

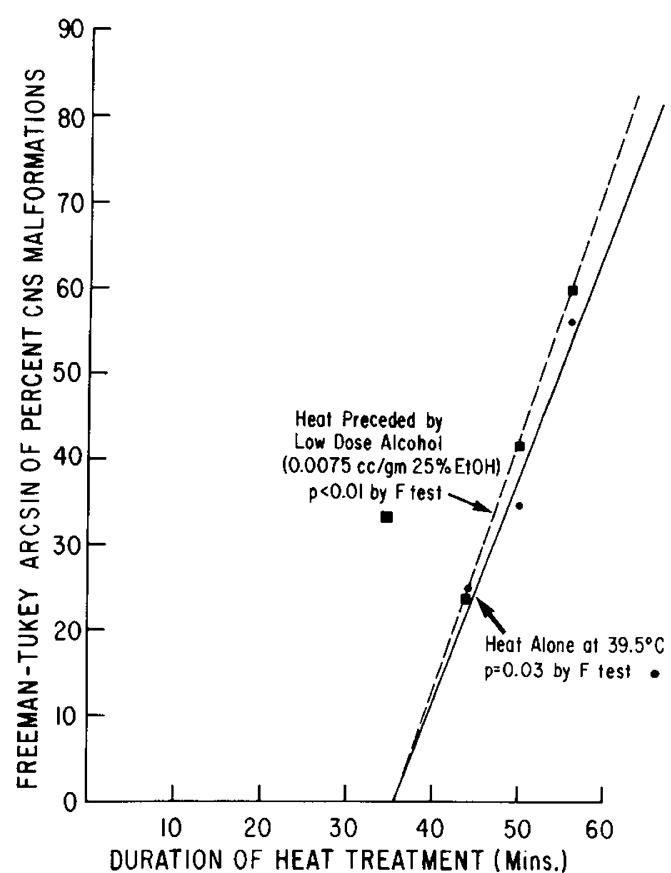

Fig. 3. Transformed percent of fetuses with NTD versus duration of maternal hyperthermia.

tube closure. Furthermore, the peripheral antifolic acid agent, Aminopterin, is reported to produce in NTD in man (32). For these reasons, our experiments were designed to determine what effect folic acid supplementation might have on experimentally induced NTD in a golden hamster model system.

The golden hamster is a well-accepted animal model system in experimental teratology (9). Golden hamsters are outbred, and, in more than 15,000 litters examined to date, Golden hamsters have been found to have less than a $0.1 \%$ spontaneous malformation rate. It is of note that NTD are not a spontaneous malformation in this animal, although they can be induced by a broad variety of teratogens administered on day 8 of gestation, which is the day of neural tube closure for this species.

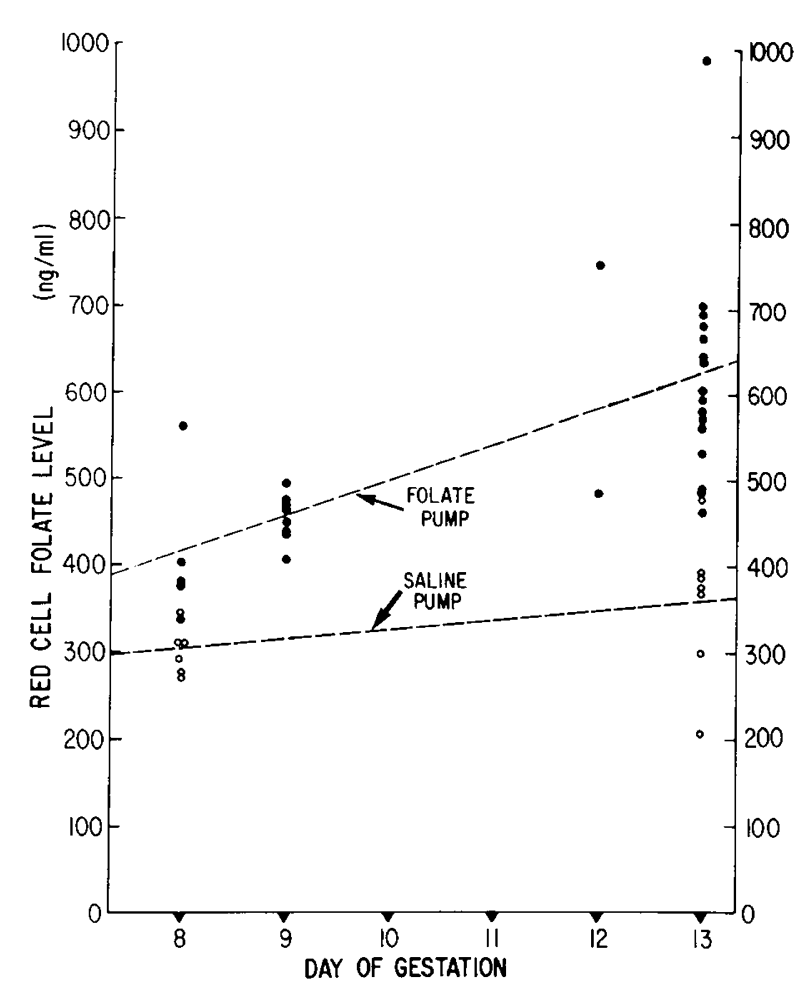

Fig. 4. Red cell folate level in pregnant golden hamsters versus day of gestation.

The studies described herein demonstrate that maternal hyperthermia and alcohol are both potent teratogens capable of inducing NTD in this model system. When mothers were supplemented with folate by means of an osmotic pump, no significant protection from NTD induced by either heat or alcohol could be demonstrated. Constant rate administration of folic acid by the osmotic minipump offers a consistent rate of exposure and results in stable maternal blood folate levels. Troughs and peaks of blood levels such as might occur with oral dosing are 
avoided through this method of exposure, and there are no difficulties with noncompliance or poor absorption. The erythrocyte folate levels achieved by means of such osmotic pumps were quite comparable to those reported by Schorah et al. (24) among mothers receiving periconceptional vitamin supplementation and demonstrating a reduced NTD recurrence rate in comparison with a group of unsupplemented mothers (30).

Recently Smithels and coworkers $(28,30)$ reported a highly significant reduction in the recurrence rate for NTD among mothers given a periconceptional multivitamin supplement containing folate, when compared with the recurrence rate for unsupplemented mothers ascertained by the same centers over the same time period. It is generally accepted that NTD in man result from the interaction of genetic and environmental factors (1), and the widely observed social class gradient in the incidence of NTD has caused some investigators to suggest the possibility of a nutritional contribution to their causation. Smithells et al. (27) demonstrated significant social class differences in nutrient intake, and Laurence et al. (18) suggested a relationship between poor diet and NTD recurrence, with possible benefits resulting from dietary counseling.

In a prospective study of blood vitamin levels during the first trimester of pregnancy, mean blood levels of folate, ascorbic acid, and riboflavin were lower in a small group of mothers who later gave birth to infants with central nervous system malformations, than in controls. The authors noted that the upper limit of erythrocyte folate levels for women who subsequently had a fetus with a NTD was $170 \mathrm{ng} / \mathrm{ml}(29)$. When a subsequent group of women was treated with a preconceptional multivitamin supplement that contained a daily dose of $0.36 \mathrm{mg}$ folic acid (given in three divided doses), mean erythrocyte folate levels rose from $250 \mathrm{ng} / \mathrm{ml}$ before supplementation, to $290 \mathrm{ng} / \mathrm{ml}$ after 28 days of supplementation, to $482 \mathrm{ng} / \mathrm{ml}$ by the $8 \mathrm{th}$ wk of pregnancy (24). By the 8 th wk, all supplemented women had erythrocyte folate levels above the $170 \mathrm{ng} / \mathrm{ml}$ level for women who had had a NTD-affected pregnancy in the previous study $(24,29)$. When the data from this cohort (30) were combined with those from a subsequent cohort, the overall recurrence rates were $0.7 \%$ for 454 fully supplemented mothers and $4.7 \%$ for 519 unsupplemented mothers (28).

A double-blind, randomized control trial of folate supplementation alone was attempted in South Wales between 1969 and 1974 , with 96 women who had previously had a child with a NTD (19). In this study, $4 \mathrm{mg}$ of folic acid or a placebo was given each day, starting not later than the 1st day of the menstrual cycle during which a pregnancy was planned and taken through the end of the 3rd month. Unfortunately, $16 \%$ of the 60 women scheduled to receive folate failed to comply; there were two NTD recurrences among these noncompliers. There were four recurrences among the 51 women allocated to receive the placebo, and no recurrences among 44 women who complied with supplementation. The difference in recurrence rate among supplemented mothers versus unsupplemented mothers was significant at the $p=0.04$ level, when the two NTD recurrences born to noncompliers were added to the four NTD recurrences born to women in the placebo group.

Results reported herein suggest that in at least one experimental animal system, folate supplementation alone is not successful in preventing alcohol- or heat-induced NTD. It is possible that mothers who are successful in remembering to take a vitamin pill prior to conception and during early gestation may also be successful in remembering to avoid known teratogens. Such daily reminders of the importance of mothering from conception and thereafter could be extremely important. Further studies are needed in order to clarify the relationship between vitamin supplementation, particularly folate supplementation, and the reductions in NTD recurrence rates that are the subjects of current reports.

Acknowledgments. We gratefully acknowledge the statistical consultation rendered by Dr. William Layton of the Department of Anatomy, Dartmouth Medical School. We are also indebted to Dr. Truls Brinck-Johnsen for erythrocyte folate determinations and to Arnold Hawk for blood alcohol determinations. We also acknowledge secretarial assistance from Ginger Bragg and the expert laboratory assistance provided by Ruth Ferm and Susan Ferm.

\section{REFERENCES}

1. Carter CO 1974 Clues to the aetiology of neural tube malformations. Dev Med Child Neurol 16:3-15

2. Chance PI, Smith DW 1978 Hyperthermia and meningomyelocele and anencephaly. Lancet 1:769-770

3. Chernoff GF 1977 The fetal alcohol syndrome in mice: an animal model. Teratology 15:223-230

4. Clarren SK, Smith DW 1978 The fetal alcohol syndrome. N Eng J Med 298:1063-1067

5. Coffey VP, Jessop WJE 1959 Maternal influenza in pregnancy and congenital deformities: a prospective study. Lancet 2:935-938

6. Doll R, Hill AB, Sukula J 1960 Asian influenza in pregnancy and congenital defects. Br J Prev Soc Med 14:167-172

7. Edwards MJ 1978 Congenital defects due to hyperthermia. Adv Vet Sci Comp Med 22:29-52

8. Edwards MJ, Wanner RA, Mulley RC 1976 Growth and development of the brain in normal and heat-retarded guinea pigs. Neuropathol Appl Neurobiol $2: 439-450$

9. Ferm VH 1967 The use of the golden hamster in experimental teratology. Lab Animal Care 17:452-462

10. Fisher NL, Smith DW 1981 Hyperthermia as a possible cause for occipital enephalocele. Pediatrics 68:480-483

11. Freidman JM 1982 Can maternal alcohol ingestation cause neural tube defects? J Pediatr 101:232-234

12. Goldstein G, Arulanantham K 1978 Neural tube defect and renal anomalies in a child with fetal alcohol syndrome. J Pediatr 93:636-637

13. Hakosalo J, Saxen L 1971 Influenza epidemic and congenital defects. Lance 2:1346-1347

14. Halperin LR, Wilroy RS 1978 Maternal hyperthermia and neural tube defects. Lancet 2:212-213

15. Kilham L, Ferm VH 1976 Exencephaly in fetal hamsters following exposure to hyperthermia. Teratology 14:323-326

16. Kronick JB 1976 Teratogenic effects of ethyl alcohol administered to pregnant mice. Am J Obstet Gynecol 124:676-680

17. Laurence KM 1982 Neural tube defects: A two-pronged approach to primary prevention. Pediatrics 70:648-650

18. Laurence KM, James N, Miller M, Campbell H 1980 Increased risk of recurrence of pregnancies complicated by fetal neural tube defects in mothers receiving poor diets, and possible benefit of dietary counselling. $\mathrm{Br}$ Med $\mathrm{J}$ 281:1592-1594

19. Laurence KM, James N, Miller MH, Tennant GB, Campbell H 1981 Doubleblind randomized controlled trial of folate treatment before conception to prevent recurrence of neural-tube defects. Br Med J 282:1509-1511

20. Loiodice G, Fiortuna G, Guidetti A, Ria N, D'Elia R 1975 Considerazioni cliniche intorno a due case di malformaxioni congenite in bambini nati da madri affette da alcolismo cronico. Minerva Pediatr 27:1891-1893

21. Miller P, Smith DW, Shepard T 1978 Maternal hyperthermia as a possible cause of anencephaly. Lancet 1:519-521

22. Randal CL; Taylor WJ 1979 Prenatal ethanol exposure in mice: teratogenic effects. Teratology 19:305-311

23. Sandor S, Elias S 1968 The influence of aethyl-alcohol on the development of the chick embryo. Rev Roum D'Embryol Ser D 5:51-76

24. Schorah CJ, Wild J, Hartley R, Sheppard S, Smithells RW 1983 The effect of periconceptional supplementation on blood vitamin concentrations in women at recurrence risk for neural tube defect. $\mathrm{Br}$ J Nutr 49:203-211

25. Shiota K 1982 Neural tube defects and maternal hyperthermia in early pregnancy: Epidemiology in a human embryo population. Am J Med Genet $12: 281-288$

26. Skreb N, Frank Z 1963 Developmental abnormalities in the rat induced by heat shock. J Embryol Exp Morphol 11:445-457

27. Smithells RW, Ankers C, Carver ME, Lennon D, Schorah C, Sheppard S 1977 Maternal nutrition in early pregnancy. Br J Nutr 38:497-506

28. Smithells RW, Seller MJ, Harris R, Fielding DW, Schorah CJ, Nevin NC, Sheppards, Read AP, Walker S, Wild J 1983 Further experience of vitamin supplementation for prevention of neural tube defect recurrences. Lancet 1:1027-1031

29. Smithells RW, Sheppard S, Schorah CJ 1976 Vitamin deficiencies and neural tube defects. Arch Dis Child 51:944-950

30. Smithells RW, Sheppard S, Schorah CJ, Seller MJ, Nevin NC, Harris R, Read AP, Fielding DW 1981 Apparent prevention of neural tube defects by periconceptional vitamin supplementation. Arch Dis Child 56:911-918

31. Sulik KK, Johnston MC, Webb MA 1981 Fetal alcohol syndrome: embryogenesis in a mouse model. Science 214:936-938

32. Thiersch JB 1952 Therapeutic abortions with folic acid antagonist, 4-aminopteroyglutamic acid ( 4 amino PGA) administered by oral route. Am J Obstet Gynecol 63:1298-1304

33. Webster WS, Walsh DA, Lipson AH, McEwen SE 1980 Teratogenesis after acute alcohol exposure in inbred and outbred mice. Neurobehav Toxicol Teratol 2:227-234 